\title{
Jean-Marc Éla's Hut and Empty Granary: Rethinking the Social Significance of Theology in Africa
}

\author{
Valentine Ugochukwu Iheanacho \\ https://orcid.org/0000-0002-1996-8527 \\ University of the Free State \\ valmsp73@gmail.com
}

\section{Abstract}

Jean-Marc Éla, in his book My Faith as an African (1988), articulates a pastoral vision for the church in Africa. According to Éla, the "friends of the gospel" must be conscious of God's presence "in the hut of a mother whose granary is empty." This awakening arises from the capacity of theologians "to catch the faintest murmurs of the Spirit," and to stay within earshot of what is happening in the ecclesial community. The vocation of an African theologian, as a witness of the faith and a travelling companion of God's people, obliges him/her "to get dirty in the precarious conditions of village life." Decades later, this thought of Éla echoes in Pope Francis' pastoral vision: "I would prefer a Church which is bruised, hurting and dirty because it has been out on the streets, rather than a Church which is unhealthy from being confined and from clinging to its security" (Evangelii Gaudium, 49). The purpose of this article is to espouse the pastoral vision of Éla in light of the liberating mission of African theologians. This mission goes beyond armchair theologising toward engaging the people of God "under the tree." With the granary understood as a metaphor for famineand famine itself being the messenger of death - the article will also argue that the "friends of the gospel" are not at liberty to shut their eyes and drift off to sleep with a clear conscience, amidst a declining African social context.

Keywords: Jean-Marc Éla; Africa; Christianity; liberation; social justice; poverty; exploitation; oppression

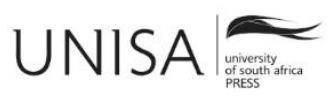




\section{Introduction}

Jean-Marc Éla insisted in his writings that it was unpardonable negligence for African Christians to bury their heads in the sand like the ostrich, since they ought to be the most concerned about the myriad of socio-economic and political problems of Africa. For Éla, the disinterestedness of African churches and their faithful about the economic and political liberation of millions of exploited and oppressed Africans, is indicative of misunderstanding the social implications of the Christian faith. This misunderstanding is connected with the brand of Christianity preached in Africa by European missionaries, which carefully respected the line of demarcation between religion and politics. This demarcation was apparently drawn in Europe, beginning with the Enlightenment period. It became more pronounced as one of the offshoots of the French Revolution from 1789 upward; although that demarcation was not always respected.

Despite the hullabaloo about that separation, there has remained a close interplay between religion and politics in European countries until recent times. The false impression about the seemingly rigid separation of church and state, and between religion and politics, has unfortunately brought about a wrong notion about the so-called "apolitical" nature of Christianity in Africa. While it is true that Christianity, as a religion, does not envisage a theocratic state of any kind, it remains misleading to assume that Christianity and politics are birds of strange feathers that are always at loggerheads.

The seminal classic of St Augustine, The City of God, is often cited to justify the noninvolvement of the church in politics. But the same Augustine was believed to have insisted that the life of a saint was a social life, with the word "socialis" understood to mean "political." The Christian vision of politics encompasses the integral well-being of the human person. It is predicated upon the inclusion of everyone in God's plan for the whole of creation, in which the human person as Imago Dei occupies a special place. Christianity rejects any domain or system that exists on the basis of wilful inattention to the human person, especially people at the margin of a political community or society. Christianity, rightly understood and lived out as part of social or political life, ought to be involved in combating everything that stands in the way of that inclusion, such as material poverty, corruption, and mismanagement of scarce resources. ${ }^{2}$ The postulation of Karl Barth about the role of theology is useful: "Where there is theological talk, it is always or implicitly political talk as well."”3

At the time of Éla, especially between the 1980s and 1990s, Africa wore the global face of poverty, famine and hunger, misery and war, sickness and death. It was against the

1 Thomas Breidenthal, "Jesus is My Neighbor: Arendt, Augustine, and the Politics of Incarnation," Modern Theology 14 no. 4 (October 1998): 490.

2 Breidenthal, "Jesus is My Neighbor," 490-493.

3 Cited in Jesse Couenhoven, "Law and Gospel, Or the Law of the Gospel? Karl Barth's Political Theology Compared with Luther and Calvin," Journal of Religious Ethics 30, no. 2 (2002): 181. 
background of these daunting African conditions that Éla became convinced that concern for the poor and the marginalised, the liberation of women and children from miseries of any kind, ought to be at the heart of Christianity in Africa. The aim of this article is to present the thoughts of Éla in relation to African liberation theology, to the social activism of the local churches and their theologians on behalf of those who with great anguish in their hearts cry out: "How long will this go on, my God?"4

\section{The Marginal Cameroonian and His Thoughts}

Jean-Marc Éla (1936-2008) has been described by Bénézet Bujo as the "African theologian of liberation par excellence," for his prodigious works and an unusual commitment to the total liberation of the African person. ${ }^{5}$ The continental emancipation envisaged by Éla entails liberation from the shackles of political and economic marginalisation together with anthropological poverty and religious subjugation, which manifest themselves through exploitation, poverty, hunger, and misery. In more than one way, he combined sociological and theological insights in his research and analysis of the African condition, and thus clearly demonstrated the inter-dependency of both disciplines; and this literary blend in his writings enriched his work. That combination was a rare and peculiar synthesis which gave a unique hue to his academic endeavours. They are the personal imprints and characteristics of the erudite Cameroonian theologian cum sociologist, who is reckoned as "one of the best known and most read African theologians both within and outside Africa." 6

As to the uniqueness of his theology, "born" as it were, out of concrete realities of rural village life, Éla himself summarises it:

I would point out that my theological reflection was born in the villages. My theology was born to be precise, under the palaver tree in the northern mountains of Cameroon. In the evenings, I gathered there with Africans of either sex to read the bible with African eyes. For fourteen years I shared their destiny and got involved in evangelizing. My theology was not born between walls made of concrete. ${ }^{7}$

Undoubtedly, that rural life experience had a great influence on the doctoral studies of Éla in sociology at the Sorbonne in Paris, which he completed in 1978. ${ }^{8}$ Again, being the fruit of direct involvement and his participation in the local community where he worked as a young priest under Baba Simon, ${ }^{9}$ his doctoral dissertation in sociology later

4 Jean-Marc Éla, My Faith as an African (Oregon: Wipf and Stock, 2019), 175.

5 Bénézet Bujo, "Jean-Marc Éla: The Champion of a Theology under the Tree," in African Theology in the 21st Century: The Contribution of the Pioneers, vol. 2, edited by Bénézet Bujo and Juvénal I.

Muya (Nairobi: Paulines Publications Africa, 2006), 182.

6 Bujo, "Jean-Marc Éla," 182.

7 Cited in Bujo, "Jean-Marc Éla," 185.

8 Bujo, "Jean-Marc Éla," 183.

9 Baba Simon was an older priest under whose direction Jean-Marc Éla, as a young priest, worked among the peasants of northern Cameroon. The old priest became a friend and a mentor to Éla, whose memory he always recalled with affection and respect. 
exerted significant influence on his thoughts and writings. It also affected his teaching career at the Faculté Protestante in the University of Yaoundé, Cameroon. It is within this perspective that his liturgical celebrations, every Saturday evening, in a parish near the University of Yaoundé in the early 1990s, remain significant. Those weekly celebrations attracted a huge gathering of students, who flocked to listen to his preaching and were inspired by his wisdom. His "radical, socially aware sermons" were ingeniously spiced with his innovative inculturation as a "rural man" who never forgot his cultural roots. ${ }^{10}$

Éla was a prolific writer but he is chiefly renowned for two works that stamp his name among contemporary African theologians. Those works are: Le cri de l'homme africain (1980)-African Cry (English title) and Ma Foi d'Africain (1988), with an English title, My Faith as an African. In those two works, Éla revealed himself first as a priest who was attentive to the practical and social demands of the Christian faith alongside the pastoral mission of the church and the theologian. There is a general estimation that Éla constantly focused on the wretched of Africa. For him, such a stance could help the church and the theologian not to remain indifferent to the poor, who, on account of their burdens and difficulties of life, had begun to misinterpret the silence of God as His abandonment of them to the chagrin of "hunger, sickness and death."11

He insisted that the church and its theologians in the African context must rediscover "le monde rurale" as the place where authentic liberation ought to begin. It is in le monde rurale that "ordinary Africans-who bear the brunt of misrule and underdevelopment-live their simple lives." Amid le monde rurale is the place where "they bear the scars of wars and conflicts." 12 Éla's disapproval in his works of the unjustifiable position of the Catholic Church in Africa "for holding to a model of faith that ignores the needs of African people, especially those in poor and rural communities" 13 may have helped to seal his fate among the marginalised. He identified the "insufficiencies and limits" of African Christianity in its "wafts above the everyday, reduced to purely religious activities, having no impact on social, economic, political and cultural realities." ${ }^{14}$ Le monde rurale was his forte, and his natural habitat, where he could notice the empty granary and ask if the question of food and sufficiency was not essential to the practice of Christianity in Africa.

Put differently, how would it be possible to ensure that those who dine and commune with the Lord Jesus Christ in the Eucharistic meal, are not left to die in the deadly harvesting hand of famine because the granaries in their village huts were empty? If the

10 Dibussi Tande, Scribbles from the Den: Essays on Politics and Collective Memory in Cameroon (Bamenda: Langaa Research and Publishing CIG, 2009), 148.

11 Éla, My Faith as an African, 94.

12 Jane I. Guyer, “In Commemoration of Jean-Marc Éla.” Accessed June 29, 2020. https://jwtc.org.za/resources/docs/salon-volume-2/janeguyer_ela.pdf.

$13 \mathrm{https} / / /$ peoplepill.com/people/jean-marc-ela/. Accessed June 29, 2020.

14 Jean-Marc Éla, African Cry (Oregon: Wipf and Stock, 2019), 91. 
affirmation is positive, he argued that Christianity and its adherents could not escape the challenge from millions of Africans who agonise over where their next meal would come from. Therefore, an active faith must translate into the rejection of any systemwhether political, economic, religious, cultural or social - that might produce empty granaries. It is not permissible for the contours of Africa to be constantly defined by famine, which Éla called "an African scourge," positioning it as a continent where the "industry of misery" flourished. ${ }^{15}$

During his lifetime, Éla was called the "spokesperson of Africa's diminishing status in the world." 16 On his death, he was fondly remembered as "le sentinelle"17 (the guard or the watchman), for his lifelong preoccupations about the situations of suffering and despair in Africa. It would be right to assert that Éla was tormented by the precariousness and scarcity that constituted the web of daily life in many places on the continent. His passion for social justice, equality, and liberation for Africans meant that Éla himself became marginalised and even ostracised, both by the Catholic Church in Cameroon and by his home country. His concern for the downtrodden meant that he was never hesitant to take on controversial issues and subjects. This included speaking for and about God in a continent where the majority of the people remain poor and often go to bed with an empty stomach. ${ }^{18}$ A similar assertion could also be made about the near-absence of the state in the lives of ordinary Africans. Karl Barth offers a pertinent question on the mutual give-and-take that should exist between the state and its citizens: "Can we give the state that respect which is its due without making its business our own, with all the consequences that this implies?"19

In a 1999 article, Éla deplored the bullying and the brutality of violence, arbitrariness, and harassment meted out against students and lecturers by several repressive African governments. He interpreted such repression directed against the ivory towers as indicative of the capability of African states for barbarity, and for the destruction of intellectual development on the continent. Indeed, such was the prevailing political climate in many African countries in the late 1990s and early 2000s. ${ }^{20}$ In another article, on religion, Éla would not look back in voicing aloud questions about God's silence. For the "uninformed," questioning God's apparent silence and remoteness in the face of misery can easily be misconstrued as an act of apostasy or even atheism. Is God

15 Éla, My Faith as an African, 87-90.

16 Philemon Beghela, “'Rethinking African Theology: Exploring the God who Liberates' by Jean-Marc Éla”. Accessed June 29, 2020. http://uir.unisa.ac.za/bitstream/handle/10500/6623/Beghela.pdf?sequence=1 .

17 Guyer, "In Commemoration of Jean-Marc Éla."

18 Beghela, "Rethinking African Theology."

19 Cited in Couenhoven, "Law and Gospel," 199.

20 Jean-Marc Éla, "Vers une économie politique des conflits au ras du sol." Africa Development/Afrique et Développement, vol. 24, no. 3/4: The Political Economy of Conflicts in Africa/Economie politique des conflits en Afrique (II) (1999), 118. 
content to see His image and likeness disfigured by misery, poverty, and deprivation? ${ }^{21}$ For Éla's temerity and criticism of the lukewarm attitude and ambivalence of the local church toward liberation and social-justice activism, Paul Gifford asserts that Éla was "totally marginalised in the Catholic Church in Cameroon," with this euphemism: "pas bien intégrê" (not well integrated). ${ }^{22}$ Despite his theological prowess and fecundity, Éla was not invited by the Cameroonian Episcopal Conference to be one of their official theologian delegates to the 1994 African Synod in Rome. The Catholic hierarchy in Cameroon was dismissive of Éla and his writings, and proffered a few reasons for his marginalisation. According to Dibussi Tande, it was common to hear disparaging comments about Éla within the Cameroonian Catholic Church: "He is just writing for the west and what he is writing has no bearing on the life of people in the village, or that he is a sociologist, not a theologian. ${ }^{, 23}$ His concerns with down-to-earth questions did not merit him any official church recognition. The church, too, is a human institution, and many times can become weary of its critics, and even repressive toward dissident views that discomfort it.

In light of his marginalisation by the Catholic Church in Cameroon, such disregard of Éla accorded him the undeclared status of persona non grata in his own country. Hence, it could be reasonably inferred that Éla, in his own manner, fully shared the fate of millions of Africans who are excluded from the social, political and economic lives of their countries. He was driven into a 13-year forced self-exile to Canada in 1995 by the dictatorial Cameroonian state. The country was, and still is, under the firm grip of Paul Biya and his Bulu ethnic supporters, who have constituted themselves into a powerful mafia group that has captured Cameroon since 1982. The harassment of intellectuals by African states, unambiguously denounced by Éla, remains symptomatic of many ailing regimes in Africa, Cameroon included. The paranoid government of Biya, because of its unwillingness to give in to the clamour for democratisation by Cameroonians in the early 1990s, increasingly resorted to repression and suppression of opposing views. The full might of the Cameroonian state was unleashed upon academic institutions in the country, which resulted in an exodus of its "brains," in search of safety and better life.

One of the unfortunate victims of this state persecution was the Cameroonian Jesuit, Father Engelbert Mveng, who was assassinated on 24 April 1995. He was one of the finest advocates of African theology, and played a significant role in the demands for an African Church council, which eventually metamorphosed into becoming an African Synod. He was alleged to have been killed by the Cameroonian state which loathed him as a "troublemaker." The circumstances surrounding his brutal death have remained mysterious, with an astonishing insinuation that he was buried without his brain by the men of Biya! ${ }^{24}$ Against the background of such a murderous atmosphere, and threats to

21 Jean-Marc Éla, "The Church: Sacrament of Liberation," in The African Synod: Documents, Reflections, Perspectives, edited by Maura Browne (New York: Orbis Books, 1996), 131-138.

22 Cited in Tande, Scribbles from the Den, 148.

23 Tande, Scribbles from the Den, 148.

24 Éla, "Vers une économie politique," 129. 
his own life after the death of Father Mveng (a close friend of his), Éla made the difficult decision to leave his beloved continent and his home country. He settled in Canada where he became a professor of sociology at the University of Laval in Montreal. He later moved to Vancouver, where he died on 26 December 2008.

The self-imposed exile precipitated by the Cameroonian government robbed Éla of any national recognition in his native land. As Tande rightly asserts: "Éla's 13-year exile ensured that the post-1990 generation of Cameroonians was completely unaware of the existence of one of the leading theologians of our times and one of the country's leading scholars of all time." ${ }^{25}$ Sharing the fate of the guard flies who went before him, he was eclipsed by the same forces of oppression and repression that he fought against throughout his life and in his writings. The tribute of Achille Mbembe in the obituary dedicated to Éla was entitled "Le veilleur s'en est alle" (The Watchman has Left us). Mbembe concisely captures the entire life and time of Éla, as well as the motifs and values that underpinned his work as a pastor, benefactor of the poor, and advocate for the identity and dignity of marginalised Africans: "He who, during half a century, made himself our tireless watchman (veilleur) and who, without respite, exhorted us to rise up and walk, he who had given his life to deciphering the night and discerning the signs of an awakening dawn, is no more." ${ }^{26}$

\section{"Crowded Churches and Empty Stomachs"27}

Abraham Maslow identifies five categories in his hierarchy of human needs. In order of importance, Maslow placed physiological needs above the other four: safety, love, esteem, and self-actualisation. According to Maslow, physiological needs are the most important in human life. They constitute the essentials that are required to sustain life on earth: food, water and shelter. ${ }^{28}$ Lessons from history have shown that development of any kind is hardly possible where these basic human needs are not met. It is hardly possible for a hungry person to concentrate on something else other than the food his or her body craves. Similar observations can be made about water and shelter. A homeless

25 Tande, Scribbles from the Den, 149.

26 Cited in Guyer, "In Commemoration of Jean-Marc Éla."

27 This subtitle is taken from Jean-Christian Ndoki Ndimba's licentiate thesis in Sacred Theology. It was presented at Boston College School of Theology and Ministry in May 2017. The full title of the thesis is: "Crowded Churches and Empty Stomachs": The Paradox of Christianity and Poverty in the Congo-Zaire Opening a Way Towards a Post-Colonial Christianity." Accessed July 2, 2020. https://dlib.bc.edu/islandora/object/bc-ir:107475/datastream/.../citation.pdf. Although the immediate locus of the thesis was the Democratic Republic of Congo, the observation and conclusion of the author mirror a bigger reality and also highlight the same phenomenon that is widespread across Africa, particularly around the sub-Saharan regions. While churches are full on a daily basis, priests being ordained and Pentecostal pastors claim a "divine mandate" to make people rich, the contrasting paradox is the widespread hunger, destitution and even despair on display on a large scale everywhere in Africa.

28 Elizabeth Hopper, "Maslow's Hierarchy of Needs Explained," ThoughtCo. Accessed July 4, 2020. https://www.thoughtco.com/maslows-hierarchy-of-needs-4582571. 
person cannot possibly sleep sufficiently to refresh the body, be productive and meaningfully contribute to society.

Any human society that ignores the physiological needs of its members, and fails to provide them, does so to its own peril. It is not surprising that Africa has yet to make tangible progress since the dawn of political independence on the continent. Taking a swipe at the African "uprooted intellectuals" of "négritude," and those who expended their energy on superficial "inculturation," Éla regrets that "While Africans were enclosed in this language of negritude and shut off from real life, others moved into the more important realms of economics and politics." 29 In Africa, poverty unfortunately assumes a feminine face. The lack of basic necessities is particularly excruciating for the womenfolk, in trying to feed themselves and their children, and even feed their husbands in some cases. Anne Nasimiya-Wasike, in her insightful article with a feminine peculiarity for details, outlines the primary needs of women in Africa. (Incidentally, it is women who make up the larger percentage of church members.) As she posits, apart from the fact that their lives are full of severe hardships due to the nonprovision of physical needs like food, water, clothing, shelter and medicine, women shoulder a disproportionate burden of the continent's underdevelopment, that overall worsens the poverty of the common folk. In that regard, women "work hard carrying the heavy burdens such as firewood, fetching water from faraway rivers and wells, planting, weeding, and harvesting crops, caring for children, grinding corn, and preparing food." ${ }^{30}$ Theirs is a struggle for the bare necessities of life, and not about theological niceties and jargons. It is sad to note that poverty, with its feminine face in Africa, "damages women and ends their lives prematurely." 31 That stark reality led Cardinal Hyacinthe Thiandoum of Dakar, at the First African Synod, to demand that "African priests must live in solidarity with the real living conditions of the people," and to avoid the temptation of becoming "part of the small cream of affluent elite in a sea of misery." 32

Pope Paul VI, in his 1976 post-synodal exhortation Evangelii Nuntiandi, made mention of those basic needs to which the church ought to give priority of attention in the proclamation of the gospel. As far as the pontiff was concerned, the church is dutybound to do so, not only because it is an essential part of evangelisation, but even more, because millions of her own children are among those who lack the primary necessities of life:

29 Éla, My Faith as an African, 147-148.

30 Anne Nasimiya-Wasike, "Christology and an African Woman's Experience," in Liberation Theology: An Introductory Reader, edited by Curt Cadorette et al. (Oregon: Wipf and Stock, 1992), 93.

31 Michael O’Sullivan, "Women, Poverty, and Christianity in Relation to Africa." Milltown Studies (Winter 1999): 103.

32 Hyacinthe Thiandoum, The Church in Africa and her Evangelising Mission towards the Year 2000. "You shall be my witnesses" (Acts 1:80) (Vatican City: EditriceVaticana, 1994), 12. 
It is well known in what terms the bishops spoke ... especially the bishops from the Third World, with a pastoral accent resonant with the voice of the millions of sons and daughters of the Church who make up those peoples. Peoples ... engaged with all their energy in the effort and struggle to overcome everything which condemns them to remain on the margin of life: famine, chronic disease, illiteracy, poverty, injustices ... The Church ... has the duty to proclaim the liberation of millions of human beings, many of whom are her own children - the duty of assisting the birth of this liberation, of giving witness to it, of ensuring that it is complete. This is not foreign to evangelisation $(E N 30){ }^{33}$

In preparation for the first African Synod, held in 1994, conferences and seminars were organised across Africa. In a paper presented by Rose Zoé-Obianga (a Cameroonian Protestant), she articulates her expectations of the synod in question format. Two of her questions remain insufficiently addressed. First: "When will the African Church become human, beautiful, strong, capable of positive verve and initiatives that promote the women and men of the continent?" Second: "When will you open yourselves up to the enormity of your situation, in the face of which you are adopting an attitude that is both ambivalent and hypocritical?"34 A prominent but unfortunate characteristic of Christianity in post-independence Africa is the overwhelming number of the poor who constitute the bulk of its membership. Acute poverty has remained a major social challenge for post-independence Africa, whose root causes are hardly identified or denounced by the churches and African theologians. This inability or reluctance of the particular churches to confront the socio-economic, political, and cultural root causes of abject poverty among their members is unquestionably one of the weak points of African Christianity — most especially as it claims to be the future and the new homeland of Christianity.

That weakness is even more vivid among the Pentecostal/Charismatic churches, whose preachers tend to attribute material poverty and misery to supernatural forces that emanate from the so-called "powers of darkness" and the devil. Their message is centred around the promise of prosperity, but without much work, and more of wishful thinking. The "Born Again" members of the Pentecostal/Charismatic churches are "assured that God materializes in his/her life and will ultimately bring prosperity," based on this formula: "Your faith + The Word of God = Miracle." 35 But regrettably, as noted by Birgit Meyer, "the trouble rather lies in the continuous experience of afflictions, from sickness to poverty, which prevent the Born Again believer from progressing in life." 36 Beyond Pentecostalism, it stands to reason that since women are the most impoverished members of every African society, they are also the ones who flock to churches. It is

33 http://www.vatican.va/content/paul-vi/en/apost_exhortations/documents/hf_pvi_exh_19751208_evangelii-nuntiandi.html. Accessed July 12, 2020.

34 Rose Zoé-Obianga, "When will the Church in Africa become African," in Towards the African Synod, edited by Giuseppe Alberigo and Alphonse N. Mushete (London: SCM Press, 1992), 89.

35 Birgit Meyer, "Pentecostalism and Neo-Liberal Capitalism: Faith, Prosperity and Vision in African Pentecostal-Charismatic Churches," Journal for the Study of Religion, vol. 20, no. 2 (2007):15.

36 Meyer, "Pentecostalism and Neo-Liberal Capitalism," 13-15. 
then no wonder as to why they give African Christianity its feminine face. This goes together with the feminisation of poverty as an unintended outcome. As Hebron Ndlovu has rightly observed by citing Tinyiko Maluleke:

The poor and marginalized are the overwhelming majority in African Christianity. The poor are the face of African Christianity... they are silent in the theologies of African Christianity. African Christianity is a Christianity of the poor, the women, the black and the underclasses. It is a Christianity of irony in the sense that though boasting numbers, it is the least powerful who swell their ranks. ${ }^{37}$

Aside from the overriding emphasis on "material blessings" by the Pentecostal/Charismatic churches, the "apolitical" stance of some conservative evangelical churches assumes that "socio-political issues fall outside the ambit of the church." ${ }^{38}$ One of the enduring criticisms of African Christianity is the late appearance of any form of political theology. This may not be totally unconnected to Leopold Senghor's theory of négritude, which emphasises cultural liberation as a constitutive aspect of African political liberation. ${ }^{39}$ Consequentially, for more than 50 years of its existence, African theology seems to have concentrated more on culture, anti-Western and anti-missionary narratives, than on the promotion of social justice and integral human development. To a large extent, it neglected important issues of poverty, famine, hunger, health, and political dictatorship. ${ }^{40}$ These issues are rampant across the continent. To complete the list is endemic corruption, that has continued to devour the rich bowels of Africa like an incurable cancer.

All these problems have persisted on the continent because, with negligible exceptions here and there, constitutional constraints and accountability seem to mean nothing to many African leaders. They often use state power and apparatus for wealth accumulation to strengthen their own material base. ${ }^{41}$ This is epitomised by the "politics of the belly," where "eating is eating," but only for the privileged elite, since "Africa does not eat uniformly." 42 Otherwise, how does a person justify the bleak economic forecast that Africans might not reach parity with the 2015 US citizen's average annual income until the year $2255 ?^{43}$ This dismaying economic picture must be put against the background of another prediction, that the population of Africa may hit 2.4 billion

37 Cited in Hebron I. Ndlovu, "African Christianity in Post-Independence Period," in Anthology of African Christianity, edited by Isabel A. Phiri et al. (Oxford: Regnum Books International, 2016), 57.

38 Ndlovu, "African Christianity," 57.

39 Ian Linden, Global Catholicism: Diversity and Change since Vatican II (New York: Columbia University Press, 2009), 201.

40 Linden, Global Catholicism, 250.

41 Claude Ake, Democracy and Development in Africa (Washington: The Brookings Institution, 1996), 4.

42 Jean-François Bayart, "Les Églises chrétiennes et la politique du ventre: le partage du gâteau ecclesial.” Accessed July 14, 2020. http://politique-africaine.com/numeros/pdf/035003.pdf.

43 Andrew Brooks, A Global History of Poverty and Prosperity (London: Zed Books, 2017), 188. 
people by $2050 .{ }^{44}$ With the remarkable exception of Jean-Marc Éla, for his efforts to incorporate "a cultural dimension into an African liberation theology," and others like Fabien Boulaga, Engelbert Mveng, Laurenti Magesa, and Barnabas Okolo, these perennial African issues and challenges are not usually considered as problematic themes needing the attention of African theologians. ${ }^{45}$

A similar view is given by Jesse Mugambi, who strongly believes that the "theology of inculturation" was a big distraction, since it failed to realise the economic and poor material conditions of Africa. This outcome is unlike what was obtained in Latin America from the late 1960s to the early 1980s. An indictment against the Catholic Church in Africa is its inability to insist that "the gospel gives hope that a life of abundance is possible not only in the life to come, but even here and now." ${ }^{46}$ While Latin American theologians worried and agonised about the economic underdevelopment and political conditions of their people, Catholic theologians, according to Mugambi, were not interested in promoting liberation theology. This might, perhaps, be ideologically explained. Liberation theology caused some ripples both in its land of origin and in Rome, where some of its proponents like Leonardo Boff and others, were subjected to ecclesiastical trials by Vatican bureaucrats. ${ }^{47}$

Perhaps also, the cautious avoidance of liberation theology by the Catholic Church in Africa in general is not altogether surprising in view of the official position assumed by the church during the pontificate of Pope John Paul II. That position became clear in 1979 at the meeting of the Latin American Bishops' Conference in Puebla, Mexico. John Paul II's speech to the gathered assembly of the Latin American bishops on 28 January 1979 is sometimes considered to have helped to steal the steam off the theology of liberation. While deploring violence in that speech, he carefully outlined what he considered to be the priorities for the church in Latin America. These were to be nonthorny issues incapable of causing any social or political disequilibrium: the family, priestly and religious vocations, and the youth. ${ }^{48}$

The position of John Paul II stood in stark contrast and diametrically opposed to the views of Latin American liberation theologians, who among other things, prioritised issues of the human person in the here and now over ecclesiastical questions. As far as the theologians were concerned, the special focus was anthropological. People are

44 Brooks, A Global History of Poverty, 188.

45 Linden, Global Catholicism, 250-251; Joseph Ogbonnaya, "African Liberative Theologies," in Introducing Liberative Theologies, edited by Miguel A. De La Torre (New York: Orbis Books, 2015), 37.

46 J. N. K. Mugambi, "Theological Method in African Christianity," in Theology and the Transformation of Africa: Tangaza Ocassional Papers, no. 10 (Nairobi: Paulines Publications Africa, 2000), 97.

47 Mugambi, "Theological Method," 98.

48 Yves Carrier, Óscar Romero: Il popolo del Salvador e il destino di un uomo (Milano: Jaca Book, 2014), 60-61. 
whom the church is called to serve, to help, to raise, and to humanise. ${ }^{49}$ The stance of John Paul was a relapse into the usual three areas of ecclesiastical preoccupation that are locked up unperturbed in their own alternative universe: sin, grace and sacraments. ${ }^{50}$ Undeniably, the prevailing situation in sub-Saharan Africa resembles in numerous ways what was obtained in Latin America, where injustice, deprivation, oppression, violence and economic mismanagement have remained endemic diseases that plague the entire continent. ${ }^{51}$

Perhaps, against the background of aforementioned harsh realities for the majority of poor and ordinary Africans, Éla may not have subscribed to the theology of reconstruction propounded by Jesse Mugambi in the early 1990s. It must not be forgotten that Mugambi's proposition was made amidst the euphoria of the 1990s after the release of Nelson Mandela from prison. It was equally made in recognition of some positive signs that timidly indicated that Africa was finally moving towards the right direction, presumably after years of conflict, corruption and sit-tight leaders. ${ }^{52}$ The decades of the 1990s and 2000s were saturated with jingoes about the illusory "African hour." The great Ghanaian international statesman and then UN Secretary, Kofi Annan, in his realistic appraisal of the moment, once cautioned Africans thus: "Let us be careful not to mistake hope for achievement." ${ }^{\text {33 }}$ Annan's wise admonition was made in Durban at the July 2002 inaugural conference of the African Union. Given the present widespread despondency and desperation across the continent, it is impossible not to agree that Annan was indeed right, and that hope or aspiration must never be mistaken for actual reality!

\section{Rediscovering the Social Mission of Theology}

In the words of the father of liberation theology, Gustavo Gutierrez, "theology follows faith. ${ }^{\circ 4}$ Ideally, theology ought to be rooted in the faith of the community, and afterward translated into praxis with regard to pastoral and social practice.$^{55}$ Praxis here implies context, and concrete actions for positive change. Appropriate contextualisation of theology serves to shield it from becoming a sterile academic pursuit for its own sake, without relevance for the lives and experiences of ordinary Christians. Any theology,

49 Leonardo Boff, "How Can We Know Christ: Toward a Christology in Latin America," in Liberation Theology: An Introductory Reader, edited by Curt Cadorette et al. (Oregon: Wipf and Stock, 1992), 88.

50 Éla, My Faith as an African, 149.

51 Ogbonnaya, "African Liberative Theologies," 26.

52 Julius Gathogo, "Jesse Mugambi’s Pedigree: Formative Factors," Studia Historiae Ecclesiasticae vol. XXXII, no. 2 (2006): 173-174. Accessed September20, 2020. http://uir.unisa.ac.za/handle/10500/4407.

53 Cited in Martin Meredith, The State of Africa: A History of Fifty Years of Independence (London, New York, 2006), 681.

54 Cited in Aylward Shorter, "Theology and the Transformation of Africa," in Theology and the Transformation of Africa: Tangaza Ocassional Papers, no. 10 (Nairobi: Paulines Publications Africa, 2000), 5.

55 Shorter, "Theology and the Transformation of Africa," 5. 
that is worth its salt, ought to emerge from the socio-cultural, economic, religious, and historical milieu of its time. ${ }^{56}$ Therefore, theology in the African context and in its various strands - inculturation, liberation, feminine, reconciliation, and reconstruction theologies - ought and must put at the centre of focus the human conditions of the African peoples. These include social, economic, cultural, political, religious, ecological and personal concerns.

This means that the concrete and variegated situations and experiences of Africans must be adequately captured in theological discourse, so as to be relevant and meaningful to the long-suffering people of the continent. In clear terms, it means that the daily lives of poor and exploited Africans must remain imperative both for the church and theologians. This latter group is called to theologise from the concreteness of the African condition, one that both impoverishes and leaves millions of Africans in despair. ${ }^{57}$ Éla was particularly insistent on this point, because he understood the role of the theologian to be that of a travelling companion of the people. Such a companion must not stand afar from the realities of the daily lives of Africans, like a hermit or a spectator. Theology becomes relevant in the African context if it remains within earshot and if it emerges from the villages and shanty-towns of Africa where people eke out a living. ${ }^{58}$

Regarding theological responsibility for change, Leonardo Boff maintains that, different from Europe, the Latin American "sky possesses different stars that form different figures of the zodiac by which we (Latin Americans) orient ourselves in the adventures of faith and life." ${ }^{59}$ Whether the church approved or not, it was inescapably involved in a transcendent context in which it was expected to respond to this disturbing question: "What will your function be?" ${ }^{60}$ However the church might choose to respond, it cannot altogether deny the liberating dimensions contained in the gospel, of which the church is the herald. Jean-Marc Éla would put the same issue in a slightly different manner with the peculiarity of the African condition. He highlights Africa's call upon the Christian conscience as one of the privileged poles of liberation, wherein God speaks incessantly to both humanity and to the church. For this reason, Éla postulates that the greatest challenge to African Christianity is how to bridge the gap between the Christian faith and liberation of the poor, since the poor will always remain at the heart of the Christian faith and ministry. It is not possible to speak of the Christian faith without speaking of liberation, because the Christian faith is essentially a revolutionary one. ${ }^{61}$

Without allowing itself to be relegated to the "sacristy," the "church must see that the demands of faith are largely rooted in the organization of the city of the earth." ${ }^{2}$ Herein

56 Ogbonnaya, "African Liberative Theologies," 26.

57 Ogbonnaya, "African Liberative Theologies," 32, 37.

58 Éla, My Faith as an African, 180, 182.

59 Boff, "How Can We Know Christ," 88,

60 Boff, "How Can We Know Christ," 90.

61 Éla, "The Church: Sacrament of Liberation," 132, 137.

62 Éla, African Cry, 135-136. 
lies the social function of theology and that of theologians, who are regarded as respected and responsible leaders of opinion in their faith communities. Beyond the convenience of theological description, analysis, and synthesis, African theologians are expected by their communities to participate actively with the rest of the members of the community to bring about the desired change in the society. ${ }^{63}$ Ultimately, this expectation:

Implies an introspection which demands the re-casting of thinking from static to the dynamic modes of thought, that propels the theologian to be changed by the circumstances in which he/she works, and equally affords him/her the possibility of influencing in turn those circumstances for good. ${ }^{64}$

Since the beginning of his pontificate in 2013, Pope Francis has been consistent in his efforts to move the Catholic Church away from a rigid and fundamentalist mindset that often keeps the church out of touch with the concrete realities of people's daily lives. Reality viewed from a distance, and especially when categorised or itemised in unintelligible theological generalities, robs the church of the opportunity to listen with open minds to people, particularly those at the margin of society and of the church itself. ${ }^{65}$ To ward off such a subtle temptation, one which is underpinned by pride, Pope Francis underscores the importance of integrating research and study, "with personal and community life, with missionary commitment, with fraternal charity and sharing with the poor." ${ }^{\prime 66} \mathrm{He}$ warns that if a church researcher "lacks the goodness and the beauty of belonging to a workaday family one ends up being an intellectual without talent, an ethicist without goodness, a thinker lacking in the splendour of beauty and only 'made up' in formalism." 67

Nowhere are his thoughts on the centrality of the social dimension of the gospel and evangelisation clearer than in his 2013 apostolic exhortation, Evangelium Gaudium, particularly section numbers 176 to 258 . There, the pontiff unequivocally maintains that efforts in the pursuit of the just ordering of society, attention to the poor and the marginalised, as well as respect for the dignity of every person, are constitutive and intrinsic parts of the mission of the church. ${ }^{68}$ As envisaged by Pope Francis, the church cannot be indifferent or unresponsive to human needs. On the contrary, those who suffer most, ought to receive before anyone else the pastoral solicitude of the church, not with

63 Mugambi, "Theological Method," 97.

64 Mugambi, "Theological Method," 97.

65 William P. Gregory, "Pope Francis's Effort to Revitalize Catholic Mission.” International Bulletin of Mission Research vol. 43, no. 1 (January 2019): 10, 13, 17.

66 http://www.vatican.va/content/francesco/en/speeches/2014/april/documents/papafrancesco_20140410_universita-consortium-gregorianum.html. Accessed July 13, 2020.

$67 \mathrm{http}: / /$ www.vatican.va/content/francesco/en/speeches/2014/april/documents/papafrancesco_20140410_universita-consortium-gregorianum.html. Accessed July 13, 2020.

68 Gregory, "Pope Francis's Effort," 10. 
mere palliatives but with tangible actions that will change their poor conditions. ${ }^{69}$ This also explains why Pope Francis is concerned about climate change, because it is the poor who suffer the most the destructive effects of climatic degradation and natural disasters. The pope's overall aim is to attend to pressing human needs as a veritable way to accomplish the mission of the church through action rather than theory.

The thoughts of Pope Francis and Jean-Marc Éla, on the social mission of the church, bear close similarities. They converge on many fronts. In the optic of Pope Francis, the church and its pastors must be in the midst of the flock to have the "smell of sheep." That will bring about a church which "is bruised, hurting and dirty because it has been out on the streets, rather than a Church which is unhealthy from being confined and from clinging to its security" ( $E G$ 24, 49). As for Éla, the preferred place of pastoral action would be "under the tree" where Christians sit side by side as brothers and sisters, and "share the lot of peasant people who seek to take responsibility for their own future and for transforming their living conditions." 70

\section{Conclusion}

This article set out to make an exposé of the theological thoughts of Jean-Marc Éla and his vision of the active role that the African Church and African theologians ought to play in the organisation of the earthly city in the African context. Ela's lifelong preoccupation was to raise awareness about the social and practical dimensions of the Christian faith in Africa. As far as he was concerned, it required the active involvement of the church and African theologians in the total liberation of poor and ordinary Africans from every shackle that prevents them from living their lives with dignity. It has been the mainstay of this article to demonstrate, through the metaphors of the "hut" and the "empty granary," how the social significance of theology cannot be overlooked in a place like Africa that has remained a continent of a great paradox. That paradox is characterised by a quagmire, since Africa is both a rich and pauper continent - almost with equal measure. In light of the continent's multi-faceted problems, and the dismal human conditions that incessantly appeal to human pity, it becomes pertinent to rediscover the constitutive social elements of the gospel for liberation. As hunger, famine and sickness continue to ravage the continent, and the avenues of opportunity for young people shrink daily, it remains to be asked: What is the social significance of African Christianity? What is the relevance of its theology to Africans?

Aside from theological euphemism like "Jesus the Elder Brother" or the "Protoancestor," folklore, music and dancing, theology in the African context cannot ignore the bleak economic conditions that African Christians share in common with other Africans. At the political level, African churches and theologians can make it their overall priority to hold African leadership accountable on behalf of many ordinary and

69 http://www.vatican.va/content/francesco/en/apost_exhortations/documents/papafrancesco_esortazione-ap_20131124_evangelii-gaudium.html. Accessed 13 July 13, 2020.

70 Éla, My Faith as an African, 180. 
voiceless Africans. The 1977 Pan-African Conference of Third World Theologians held in Accra, declared that its theology "arises from and is accountable to the African people." $"$ The time has come to inquire about what has become of that declaration 43 years later. Amidst all the challenges and difficulties of Africa, Jean-Marc Éla's admonition remains evergreen: "A god who is not committed to the victory of humanity over material poverty, misery, injustice and oppression is an idol." $" 72$ This also holds true for a church and a theology that are remote from the living conditions of the Christian communities in Africa.

\section{References}

Ake, Claude. Democracy and Development in Africa. Washington: The Brookings Institution, 1996.

Bayart, J. F. "Les Églises chrétiennes et la politique du ventre: le partage du gâteau ecclesial." Accessed July 14, 2020. http://politique-africaine.com/numeros/pdf/035003.pdf.

Beghela, Philemon. “'Rethinking African Theology: Exploring the God who Liberates,' by Jean-Marc Éla.” Accessed June 29, 2020.

http://uir.unisa.ac.za/bitstream/handle/10500/6623/Beghela.pdf?sequence=1.

Boff, Leonardo. "How Can We Know Christ: Toward a Christology in Latin America." In Liberation Theology: An Introductory Reader, edited by Curt Cadorette et al. Oregon: Wipf and Stock, 1992, 88-91.

Breidenthal, Thomas. "Jesus is My Neighbor: Arendt, Augustine, and the Politics of Incarnation.” Modern Theology 14 (4) (October 1998): 489-503. https://doi.org/10.1111/1468-0025.00076.

Brooks. Andrew. A Global History of Poverty and Prosperity. London: Zed Books, 2017.

Bujo, Bénézet. “Jean-Marc Éla: The Champion of a Theology under the Tree.” In African Theology in the 21st Century: The Contribution of the Pioneers, vol. 2, edited by BénézetBujo and Juvénal I. Muya. Nairobi: Paulines Publications Africa, 2006, 182-214.

Carrier, Yves. Óscar Romero: Il popolo del Salvador e il destino di un uomo. Milano: Jaca Book, 2014.

Couenhoven, Jesse. "Law and Gospel, Or the Law of the Gospel? Karl Barth's Political Theology Compared with Luther and Calvin.” Journal of Religious Ethics 30 (2) (2002): 181-205. https://doi.org/10.1111/1467-9795.00103.

Éla, Jean-Marc. My Faith as an African. Oregon: Wipf and Stock, 2019.

71 Cited in Éla, My Faith as an African, 176.

72 Éla, My Faith as an African, 179. 
Éla, Jean-Marc. African Cry. Oregon: Wipf and Stock, 2019.

Éla, Jean-Marc. "Vers une économie politique des conflits au ras du sol." Africa Development/Afrique et Développement 24 (3/4): The Political Economy of Conflicts in Africa/Economie politique des conflits en Afrique (II) (1999), 103-133. https://doi.org/10.4314/ad.v24i3.22128.

Éla, Jean-Marc. "The Church: Sacrament of Liberation.” In The African Synod: Documents, Reflections, Perspectives, edited by Maura Browne. New York: Orbis Books, 1996, 131138.

Gathogo, Julius. “Jesse Mugambi’s Pedigree: Formative Factors.” Studia Historiae Ecclesiasticae XXXII (2) (2006):173-205. Accessed September 20, 2020. http://uir.unisa.ac.za/handle/10500/4407.

Gregory, William P. "Pope Francis's Effort to Revitalize Catholic Mission.” International Bulletin of Mission Research 43 (1) (January 2019): 7-19. https://doi.org/10.1177/2396939318795374.

Guyer, Jane I. “In Commemoration of Jean-Marc Éla.” Accessed June 29, 2020. https://jwtc.org.za/resources/docs/salon-volume-2/janeguyer_ela.pdf.

Hopper, Elizabeth. "Maslow's Hierarchy of Needs Explained.” ThoughtCo. Accessed July 4, 2020. https://www.thoughtco.com/maslows-hierarchy-of-needs-4582571.

Linden, Ian. Global Catholicism: Diversity and Change since Vatican II. New York: Columbia University Press, 2009.

Meredith, Martin. The State of Africa: A History of Fifty Years of Independence. London, New York, 2006.

Meyer, Birgit. "Pentecostalism and Neo-Liberal Capitalism: Faith, Prosperity and Vision in African Pentecostal-Charismatic Churches." Journal for the Study of Religion 20 (2) (2007): 5-28. https://doi.org/10.4314/jsr.v20i2.47769.

Mugambi, J. N. K. "Theological Method in African Christianity.” In Theology and the Transformation of Africa: Tangaza Ocassional Papers, No. 10. Nairobi: Paulines Publications Africa, 2000, 69-100.

Nasimiya-Wasike, AI could not find a text reference to this source. Please add at an appropriate place or delete from the list of references.nne. "Christology and an African Woman's Experience.” In Liberation Theology: An Introductory Reader, edited by Curt Cadorette et al. Oregon: Wipf and Stock, 1992, 92-103.

Ndlovu, Hebron I. "African Christianity in Post-Independence Period.” In Anthology of African Christianity, edited by Isabel A. Phiri et al. Oxford: Regnum Books International, 2016, 53-64. 
Ndoki Ndimba, Jean-Christian. "Crowded Churches and Empty Stomachs: The Paradox of Christianity and Poverty in the Congo-Zaire Opening a Way Towards a Post-Colonial Christianity.” Boston: Unpublished, 2017. Accessed July 2, 2020.

https://dlib.bc.edu/islandora/object/bc-ir:107475/datastream/.../citation.pdf..

Ogbonnaya, Joseph. “African Liberative Theologies.” In Introducing Liberative Theologies, edited by Miguel A. De La Torre. New York: Orbis Books, 2015, 26-46.

O’Sullivan, Michael. "Women, Poverty, and Christianity in Relation to Africa." Milltown Studies (Winter 1999): 103-129.

Shorter, Aylward. "Theology and the Transformation of Africa." In Theology and the Transformation of Africa: Tangaza Ocassional Papers, No. 10. Nairobi: Paulines Publications Africa, 2000, 5-8.

Tande, Dibussi. Scribbles from the Den: Essays on Politics and Collective Memory in Cameroon. Bamenda: Langaa Research and Publishing CIG, 2009.

Thiandoum, Hyacinthe. The Church in Africa and her Evangelising Mission towards the Year 2000. "You shall be my witnesses" (Acts 1:80). Vatican City: Editrice Vaticana, 1994.

Zoé-Obianga, Rose. "When will the Church in Africa become African." In Towards the African Synod, edited by Giuseppe Alberigo and Alphonse N. Mushete. London: SCM Press, 88-91.

\section{Internet Sources}

https://peoplepill.com/people/jean-marc-ela/. Accessed June 29, 2020.

http://www.vatican.va/content/paul-vi/en/apost_exhortations/documents/hf_pvi_exh_19751208_evangelii-nuntiandi.html. Accessed July 12, 2020.

http://www.vatican.va/content/francesco/en/speeches/2014/april/documents/papafrancesco_20140410_universita-consortium-gregorianum.html. Accessed July 13, 2020. http://www.vatican.va/content/francesco/en/apost_exhortations/documents/papafrancesco_esortazione-ap_20131124_evangelii-gaudium.html. Accessed July 13, 2020. 